\title{
Frequency of providing a palliative approach to care in family practice: a chart review and perceptions of healthcare practitioners in Canada
}

Erin Gallagher ${ }^{1,2}$, Daniel Carter-Ramirez ${ }^{1,2}$, Kaitlyn Boese ${ }^{3,4}$, Samantha Winemaker ${ }^{1,2}$, Amanda MacLennan ${ }^{1,2}$, Nicolle Hansen ${ }^{1}$, Abe Hafid ${ }^{1}$ and Michelle Howard ${ }^{1 *}$

\begin{abstract}
Background: Most patients nearing the end of life can benefit from a palliative approach in primary care. We currently do not know how to measure a palliative approach in family practice. The objective of this study was to describe the provision of a palliative approach and evaluate clinicians' perceptions of the results.

Methods: We conducted a descriptive study of deceased patients in an interprofessional team family practice. We integrated conceptual models of a palliative approach to create a chart review tool to capture a palliative approach in the last year of life and assessed a global rating of whether a palliative approach was provided. Clinicians completed a questionnaire before learning the results and after, on perceptions of how often they believed a palliative approach was provided by the team.

Results: Among 79 patients (mean age at death 73 years, 54\% female) cancer and cardiac diseases were the top conditions responsible for death. One-quarter of patients were assessed as having received a palliative approach. 53\% of decedents had a documented discussion about goals of care, $41 \%$ had nurse involvement, and $15.2 \%$ had a discussion about caregiver well-being. These indicators had the greatest discrimination between a palliative approach or not. Agreement that elements of a palliative approach were provided decreased significantly on the clinician questionnaire from before to after viewing the results.
\end{abstract}

Conclusions: This study identified measurable indicators of a palliative approach in family practice, that can be used as the basis for quality improvement.

Keywords: Primary care, Palliative care, Inter-professional, Practice review

*Correspondence: mhoward@mcmaster.ca

'Department of Family Medicine, McMaster University, David Braley

Health Sciences Centre 100 Main Street West, 5th Floor, Hamilton, ON L8P

$1 \mathrm{H} 6$, Canada

Full list of author information is available at the end of the article

(c) The Author(s) 2021. Open Access This article is licensed under a Creative Commons Attribution 4.0 International License, which permits use, sharing, adaptation, distribution and reproduction in any medium or format, as long as you give appropriate credit to the original author(s) and the source, provide a link to the Creative Commons licence, and indicate if changes were made. The images or other third party material in this article are included in the article's Creative Commons licence, unless indicated otherwise in a credit line to the material. If material is not included in the article's Creative Commons licence and your intended use is not permitted by statutory regulation or exceeds the permitted use, you will need to obtain permission directly from the copyright holder. To view a copy of this licence, visit http://creativecommons.org/licenses/by/4.0/. The Creative Commons Public Domain Dedication waiver (http://creativeco mmons.org/publicdomain/zero/1.0/) applies to the data made available in this article, unless otherwise stated in a credit line to the data. 


\section{Background}

There is increasing evidence revealing the benefits of palliative care for patients with chronic, progressive lifelimiting illness [1-6]. Fewer people are dying suddenly and most will live for a period of time with high healthcare and other needs [7]. Despite this knowledge, efforts to integrate, describe and evaluate palliative care in and across the healthcare system have not achieved the level of uptake and sustainability required [8-12]. Indeed, the World Health Organization has called for standardized access to palliative care as a human right [13]. Countries including Canada and the U.S. have taken steps to create strategies to help organizational change and planning to support policy and program decision making $[14,15]$. Aging Canadians experience access and equity challenges, with only $15 \%$ receiving home palliative care and most palliative care being initiated due to unplanned hospital admissions or emergency department visits [16]. This promotes a sense of urgency for solutions [17].

Although government prioritization of palliative care is a promising development and it is recognized that primary care can contribute to addressing the majority of palliative care needs in the population [18], there remains a lack of conceptual clarity around certain aspects, including the differentiation of primary and specialist levels of palliative care, what they are comprised of and when each is needed $[19,20]$. The phrase palliative approach has gained traction due to connotations of activities or tasks (not just philosophy) applicable to all care professionals (not just palliative care specialists) in a manner consistent with the philosophy of palliative care, regardless of whether care is labelled or approached as such $[19,21]$. Sawatzky and colleagues identified three overarching themes delineating a palliative approach: (1) upstream orientation towards the needs of people who have life-limiting conditions and their families, (2) adaptation of palliative care knowledge and expertise, (3) operationalization of a palliative approach through integration into systems and models of care that do not specialize in palliative care [9].

In Canada and elsewhere, it is recognized that family medicine is a specialty in which a primary palliative approach would be ideally situated [22, 23] due to the provision of comprehensive care across the lifespan [24]. Investment in primary care health service delivery improves the overall health of populations and reduces inequity in healthcare distribution and health outcomes within populations [25]. The principles and activities of family medicine contribute to outcomes for patients with progressive life-limiting illness through coordination and continuity of care, care decision-making, care planning and referral to specialist care as needed [26-29]. Continuity of care with primary care providers has been shown to be valued by patients with chronic, progressive lifelimiting illness [26, 30-32] and is cost-effective for the system $[33,34]$.

If healthcare systems are to respond to population needs for palliative care by promoting a primary level palliative approach, this care must be both conceptually clear and operationally defined and measurable. Measuring and supporting high quality primary care remains a challenge [25]. Tools and competencies exist to support family medicine in adopting a primary level palliative approach [11, 23, 35]. Nevertheless, there is evidence that generalists are not certain how to incorporate the approaches into practice [36]. Attempts to codify and measure whether and how elements of a palliative approach are applied in this setting have been limited $[21,28,31]$.

To address the gap between conceptual descriptions and competencies, and observable measurable care processes in practice, in our previous work, we qualitatively described a palliative approach to care (PAC) in primary care, from the perspective of primary care physicians and nurses caring for patients with progressive life-limiting illnesses [2]. In this study, we sought to measure the extent to which PAC is provided in a large, urban interprofessional family health team (FHT) setting in one city in Canada. To assess the extent to which the outcomes resonated as a potential quality improvement opportunity, we also assessed the clinicians' perception of how consistently the FHT provides elements of PAC, before and after learning about the results.

\section{Methods}

We conducted a cross-sectional study to determine, by chart review, how consistently one FHT was implementing elements of PAC with patients in their last year of life. We chose the last year of life to align with literature showing sharp increases in levels of disability in the last year of life [37], the frequent reference to the last year of life in recommendations to initiate palliative care [38], and recognizing that a palliative approach to care should be incorporated from the time of diagnosis of a progressive life-limiting illness [12].

The study was conducted in an FHT made up of two multi-physician family medicine clinics in one city, serving approximately 40,000 patients. There are 40 family physician practices, diverse allied health professionals who work between practices and 80 family medicine residents. One hundred patient charts were randomly selected among 192 patients who died from January $1^{\text {st }}$ to December $31^{\text {st }}, 2017$. With inter-rater reliability being previously established, charts were equally divided between 2 reviewers for data extraction. Inclusion criteria were patients who had been a member of the practice for 
at least 1 year prior to their death and had a chronic, progressive life-limiting illness. Exclusion criteria included: orphan patients (admitted to the practice at end of life for the sole purpose of palliative care and not having a previously identified family doctor); sudden and unexpected deaths unrelated to a chronic progressive life-limiting illness; and patients residing in a long-term care facility for over 6 months of the last year of their life.

We created a chart review tool to capture the elements of PAC in primary care (Additional file 1). To develop the tool, we combined the three aforementioned conceptual domains of a palliative approach, and three core elements of published definitions of what constitutes palliative care from another systematic review. The three conceptual domains (early upstream approach, adaptation of palliative care knowledge and expertise to other settings, integration into systems) [19] and three elements of the definition (whole person care, quality of life focus, mortality acknowledgement) [9] were linked to the operational items/elements in the chart review form to create a tool for evaluating PAC in primary care. Categories in the final chart audit form included advance care planning topics documented, symptoms documented, type of clinicians involved in care, frequency of telephone contacts and home visits, involvement of formal home care services and attention to caregiver involvement and well-being. For descriptive purposes we also collected information on demographics, health conditions and illnesses most responsible for death.

Since there is no current operational definition of a palliative approach, the chart reviewers provided an overall assessment of their judgement of whether the care given by the family practice in the last year of life aligned with PAC. To make this assessment of having received PAC, patients required clinical documentation of elements mapping to all 3 domains. For practicality and to ensure the focus was on the efforts of the primary care team, documentation considered included the chart's running commentary and the cumulative patient profile only. Consultant notes, messages and external documents were not considered because we wanted to capture care provided by the family practice, and because it was not practicable to review the volume of information. The timeframe for the chart review and assessment of a palliative approach was one year prior to the patient's death.

For reasons of feasibility, we randomly selected 100 charts to review. Patient characteristics and outcomes of interest were described using mean (standard deviation) for continuous variables and count (percent) for categorical variables. For comparisons of outcomes between patients who did and did not receive a PAC, independent sample t-tests (for continuous data) and Pearson's
Chi-squared tests (for categorical data) or Fisher's exact tests (for categorical data with expected cell sizes $<5$ ) were used. Haldane's correction was applied to contingency tables with observed zero values. Statistical significance of comparisons was indicated by a $p$-value $<0.05$ (two-tailed) for the test. For comparisons of proportions, an absolute difference of $30 \%$ between groups could be detected with $80 \%$ power, and there was greater than $80 \%$ power to detect a mean difference of 1.0 between groups for continuous variables.

Following data analyses, results were presented to clinicians within the FHT $(N=58)$ in a group meeting. A pre- and post- questionnaire was administered immediately before and then after the presentation, to determine perceptions around how consistently clinicians perceived they delivered the elements of a palliative approach. The questionnaire was developed by this study and has not been published elsewhere (Additional file 2). The survey included 8 questions and used 7-point Likert scale responses $(1=$ infrequently, $7=$ regularly). The difference in mean scores for each question were compared by the paired t-test. Analyses were conducted using SAS๑ software, version 9.4 for Windows.

The STROBE checklist for cross-sectional studies was used. Ethics approval for the chart review was received by the Hamilton Integrated Research Ethics Board for this project (File number 2017-4204-C). We did not seek ethics approval for the anonymous staff questionnaire as this was undertaken to inform potential quality improvement efforts locally, as per Canada's Tri-Council Policy Statement: Ethical Conduct for Research Involving Humans -TCPS 2 (2018) Article 2.5. We explained the purpose of the questionnaire and informed staff that completion was voluntary. Individual respondent consent was not elicited and was assumed by completion of the questionnaire.

\section{Results}

Of the 100 randomly selected patients, 13 were excluded because they were patients without a family physician only transferred to the practice near end of life, four died suddenly of reasons unrelated to chronic life-limiting illness, and four were transferred to a long-term care institution. The remaining seventy-nine patients met inclusion criteria for the chart review. The mean age at death was 73.1 years; $54.4 \%$ were female; $79.7 \%$ had an unpaid caregiver recognized in the chart. The most common life-limiting diagnoses were cancer (49.4\%) and endstage cardiac diseases (40.5\%). Over half of patients had a non-cancer diagnosis as the most attributable cause of death (Table 1).

There was variability across care processes, for example, from 1.3\% (evidence of involvement of an FHT social worker in care) to $44.3 \%$ (evidence of involvement of a 
Table 1 Characteristics of the 79 decedents from the Family Health Team

\begin{tabular}{|c|c|}
\hline Characteristic & $\begin{array}{l}\mathrm{N}(\%) \text { or mean, } \\
\text { standard } \\
\text { deviation (SD) }\end{array}$ \\
\hline Mean (SD) age at death, $y$ & $73.1(14.7)$ \\
\hline Age range, y & 37 to 99 \\
\hline Female sex & $43(54.4)$ \\
\hline \multicolumn{2}{|l|}{ Marital status } \\
\hline Not in a relationship & $18(22.8)$ \\
\hline In a relationship (not living together) & $3(3.8)$ \\
\hline Married or common-law (living together) & $35(44.3)$ \\
\hline Not documented in chart & $23(29.1)$ \\
\hline \multicolumn{2}{|l|}{ Education status } \\
\hline Did not complete high school & $1(1.3)$ \\
\hline Completed high school & $0(0.0)$ \\
\hline $\begin{array}{l}\text { Had some university education or completed a com- } \\
\text { munity college, technical college, or post-secondary } \\
\text { program (ex. trade, technical, or vocational school) }\end{array}$ & $2(2.5)$ \\
\hline University degree (ex. BA, BSc, BSN) & $5(6.3)$ \\
\hline $\begin{array}{l}\text { Graduate degree (ex. MD, DDS, DMD, DVM, OD, } \\
\text { Master's, or PhD) }\end{array}$ & $2(2.5)$ \\
\hline Not documented in chart & $69(87.3)$ \\
\hline \multicolumn{2}{|l|}{ Residence status } \\
\hline At home (apartment/townhouse/bungalow) & $60(75.9)$ \\
\hline Retirement residence & $4(5.1)$ \\
\hline Supportive housing (group home/assisted living) & $2(2.5)$ \\
\hline Long-term care or nursing home & $1(1.3)$ \\
\hline $\begin{array}{l}\text { Vulnerable housing (shelter/transition home/no } \\
\text { home/subsidized housing) }\end{array}$ & $0(0.0)$ \\
\hline Not documented in chart & $12(15.2)$ \\
\hline \multicolumn{2}{|l|}{ Living alone prior to death } \\
\hline Yes & $16(20.3)$ \\
\hline No & $43(54.4)$ \\
\hline Not documented in chart & $20(25.3)$ \\
\hline \multicolumn{2}{|l|}{ Living with their caregiver } \\
\hline Yes & $42(53.2)$ \\
\hline No & $13(16.5)$ \\
\hline Not documented in chart & $24(30.4)$ \\
\hline \multicolumn{2}{|l|}{ Identified a caregiver in their chart } \\
\hline Yes & $63(79.7)$ \\
\hline No & $16(20.3)$ \\
\hline \multicolumn{2}{|l|}{ Documented caregiver presence at office visits } \\
\hline Yes & $47(59.5)$ \\
\hline No & $32(40.5)$ \\
\hline \multicolumn{2}{|l|}{ Documented caregiver's concerns being addressed } \\
\hline Yes & $39(49.4)$ \\
\hline No & $40(50.6)$ \\
\hline \multicolumn{2}{|l|}{ Documented caregiver's well being addressed } \\
\hline Yes & $12(15.2)$ \\
\hline No & $67(84.8)$ \\
\hline \multicolumn{2}{|l|}{ Documentation of chronic life-limiting illness } \\
\hline Cancer & $39(49.4)$ \\
\hline
\end{tabular}

Table 1 (continued)

\begin{tabular}{ll}
\hline Characteristic & $\begin{array}{l}\text { N (\%) or mean, } \\
\text { standard } \\
\text { deviation (SD) }\end{array}$ \\
\hline Cardiac disease & $32(40.5)$ \\
Mental health & $18(22.8)$ \\
Lung disease & $12(15.2)$ \\
Frailty & $11(13.9)$ \\
Renal disease & $10(12.7)$ \\
Dementia & $9(11.4)$ \\
Liver disease & $7(8.9)$ \\
Stroke & $6(7.6)$ \\
Neurodegenerative disease & $1(1.3)$ \\
Other & $7(8.9)$ \\
IIIness most responsible for death & \\
Cancer & $33(41.8)$ \\
Cardiac disease & $16(20.3)$ \\
Mental health & $3(3.8)$ \\
Stroke & $3(3.8)$ \\
Frailty & $2(2.5)$ \\
Liver disease & $2(2.5)$ \\
Lung disease & $2(2.5)$ \\
Dementia & $1(1.3)$ \\
Neurodegenerative disease & $1(1.3)$ \\
Renal Disease & $1(1.3)$ \\
Other & $15(19.0)$ \\
Documented chronic life-limiting illnesses, mean (SD) & $1.9(0.9)$ \\
&
\end{tabular}

FHT nurse). The care processes documented for most patients included addressing physical symptoms (89.9\% of patients), followed by documentation of caregivers being present at visits (59.5\%) and caregiver concerns documented (49.4\%) (Table 2). Infrequent care processes included use of symptom assessment tools (6.3\%) and discussion of cultural or religious concerns (e.g., rituals or beliefs that would impact care) regarding end of life (1.3\%).

Twenty (25\%) of the patients were assessed as having received a PAC by our criteria. PAC patients tended to be older compared to non-PAC patients (mean age 78.3 vs 71.4 years; $p=0.07$ ); more likely to be female $(60 \%$ vs $52.5 \% ; p=0.69)$ and have a higher number of documented life-limiting illnesses (mean 2.2 versus 1.8; $p=0.18$ ), although these differences were not statistically significant.

Patients with cancer $(60.0 \%$ versus $45.8 \% ; p=0.27)$, cardiac disease $(50.0 \%$ versus $37.3 \% ; p=0.32)$ or renal disease $(25.0 \%$ versus $8.5 \%$; $p=0.11)$ were more likely to receive PAC than those without the conditions, although the differences were not statistically significant.

The care processes with the greatest difference between PAC and non-PAC patients were: discussion about values, beliefs, and priorities as part of advance care 
Table 2 Processes of care documented in decedents $(n=79)$ who did versus did not receive a palliative approach to care

\begin{tabular}{|c|c|c|c|c|}
\hline \multirow[t]{2}{*}{ Variables documented in electronic medical record } & \multirow{2}{*}{$\begin{array}{l}\text { Overall } \\
(n=79), n \\
(\%)\end{array}$} & \multicolumn{2}{|c|}{$\begin{array}{l}\text { Did the patient receive a palliative approach to } \\
\text { care? }\end{array}$} & \multirow[t]{2}{*}{$P$-value ${ }^{\text {ab }}$} \\
\hline & & Yes $(N=20), n(\%)$ & No $(\mathrm{N}=59), \mathrm{n}(\%)$ & \\
\hline \multicolumn{5}{|l|}{ Mortality Acknowledgement } \\
\hline \multicolumn{5}{|l|}{ Advance Care Planning topics addressed and documented: } \\
\hline Goals of care for treatment decisions (to pursue a treatment or not and why) & $42(53.2)$ & $18(90)$ & $24(40.7)$ & $<.01$ \\
\hline Understanding of severity of illness (illness awareness) & $32(40.5)$ & $17(85)$ & $15(25.4)$ & $<.01$ \\
\hline Values/beliefs/priorities moving forward & $26(32.9)$ & $18(90)$ & $8(13.6)$ & $<.01$ \\
\hline Do-Not-Resuscitate \& Do-Not-Resuscitate Confirmation Form & $20(25.3)$ & $15(75)$ & $5(8.5)$ & $<.01$ \\
\hline Power of Attorney for Personal Care \& Substitute Decision Makers & $18(22.8)$ & $9(45)$ & $9(15.3)$ & .01 \\
\hline Desired place of death & $13(16.5)$ & $11(55)$ & $2(3.4)$ & $<.01$ \\
\hline Prognosis & $11(13.9)$ & $11(55)$ & $0(0)$ & $<.01$ \\
\hline Will & $2(2.5)$ & $2(10)$ & $0(0)$ & .06 \\
\hline Funeral arrangements & $2(2.5)$ & $2(10)$ & $0(0)$ & .06 \\
\hline Other & $5(6.3)$ & $2(10)$ & $3(5.1)$ & .60 \\
\hline \multicolumn{5}{|l|}{ Quality of Life } \\
\hline \multicolumn{5}{|l|}{ Homecare involvement documented: } \\
\hline Nurse & $32(40.5)$ & $17(85)$ & $15(25.4)$ & $<.01$ \\
\hline Personal Support Worker & $22(27.8)$ & $10(50)$ & $12(20.3)$ & .01 \\
\hline Occupational Therapist & $8(10.1)$ & $5(25)$ & $3(5.1)$ & .02 \\
\hline Physiotherapist & $4(5.1)$ & $2(10)$ & $2(3.4)$ & .26 \\
\hline Psychosocial/Spiritual Advisor & $3(3.8)$ & $3(15)$ & $0(0)$ & .01 \\
\hline Registered Dietitian & $2(2.5)$ & $1(5)$ & $1(1.17)$ & .38 \\
\hline Other & $12(15.2)$ & $1(5)$ & $11(18.6)$ & .28 \\
\hline \multicolumn{5}{|l|}{ Quality of Life focused symptom discussions documented: } \\
\hline Physical Symptoms & $71(89.9)$ & $19(95)$ & $52(88.1)$ & .67 \\
\hline Delirium & $8(10.1)$ & $8(40)$ & $0(0)$ & $<.01$ \\
\hline Symptom Assessment Tools used & $5(6.3)$ & $2(10)$ & $3(5.1)$ & .60 \\
\hline Other & $1(1.3)$ & $1(5)$ & $0(0)$ & .25 \\
\hline \multicolumn{5}{|l|}{ Whole-person Care } \\
\hline \multicolumn{5}{|l|}{ Primary care involvement documented: } \\
\hline Most Responsible Physician & $68(86.1)$ & $20(100)$ & $48(81.4)$ & .06 \\
\hline Medical Resident & $59(74.7)$ & $18(90)$ & $41(69.5)$ & .08 \\
\hline Nurse & $35(44.3)$ & $14(70)$ & $21(35.6)$ & .007 \\
\hline Pharmacist & $17(21.5)$ & $4(20)$ & $13(22.0)$ & 1.00 \\
\hline Occupational Therapist & $10(12.7)$ & $1(5)$ & $9(15.3)$ & .44 \\
\hline Registered Dietitian & $5(6.3)$ & $0(0)$ & $5(8.5)$ & .32 \\
\hline Physiotherapist & $2(2.5)$ & $0(0)$ & $2(3.4)$ & 1.00 \\
\hline Social Worker & $1(1.3)$ & $1(5)$ & $0(0)$ & .25 \\
\hline Other & $23(29.1)$ & $5(25)$ & $18(30.5)$ & .64 \\
\hline \multicolumn{5}{|l|}{ Caregiver involvement and status documented: } \\
\hline Caregiver presence documented & $47(59.5)$ & $18(90.0)$ & $29(49.2)$ & .01 \\
\hline Caregiver concerns documented & $39(49.4)$ & $18(90.0)$ & $21(35.6)$ & $<.01$ \\
\hline Caregiver well-being documented & $12(15.2)$ & $9(45.0)$ & $3(5.1)$ & $<.01$ \\
\hline \multicolumn{5}{|l|}{ Whole-person care focused symptom discussions documented: } \\
\hline Existential/psychosocial/spiritual concerns & $33(41.8)$ & $16(80)$ & $17(28.8)$ & $<.01$ \\
\hline Safety concerns & $26(32.9)$ & $11(55)$ & $15(25.4)$ & .02 \\
\hline Financial concerns & $17(21.5)$ & $7(35)$ & $10(16.9)$ & .11 \\
\hline Cultural concerns & $1(1.3)$ & $0(0)$ & $1(1.7)$ & 1.00 \\
\hline Phone care documented as 'Often' $(5 \text { or more phone calls })^{d}$ & $33(43.4)$ & $15(75)$ & $18(32.1)$ & $<.01$ \\
\hline Documented number of home visits in final year of life, mean (SD) & $2.3(7.1)$ & $4.0(5.1)$ & $1.7(7.6)$ & $.21^{c}$ \\
\hline
\end{tabular}

aPearson's Chi-Squared Test

${ }^{\text {b} F i s h e r ' s ~ E x a c t ~ T e s t ~ f o r ~ c a t e g o r i c a l ~ d a t a ~ w i t h ~ e x p e c t e d ~ c e l l ~ s i z e s ~}<5$

Independent samples t-test

${ }^{\mathrm{d} O v e r a l l ~ s a m p l e ~ o f ~} N=76$ due to incomplete chart reviews 
Table 3 Rating of consistency of providing a palliative approach ( $1=$ infrequently, 7 = regularly) by Family Health Team

\begin{tabular}{|c|c|c|c|}
\hline \multirow[t]{2}{*}{ Survey question } & \multicolumn{2}{|c|}{ Mean, standard deviation } & \multirow[t]{2}{*}{$P$-value } \\
\hline & Before & After & \\
\hline $\begin{array}{l}\text { How consistently does your clinic provide a palliative approach to care for patients with chronic, progres- } \\
\text { sive, life-limiting illnesses? }\end{array}$ & $5.0(1.2)$ & $3.8(1.3)$ & $<.01$ \\
\hline $\begin{array}{l}\text { How consistently does your clinic provide whole-person care to patients with chronic, progressive, life- } \\
\text { limiting illnesses? }\end{array}$ & $5.5(1.1)$ & $4.4(1.5)$ & $<.01$ \\
\hline $\begin{array}{l}\text { How consistently does your clinic provide a quality-of-life focus to patients with chronic, progressive, life- } \\
\text { limiting illnesses? }\end{array}$ & $5.5(1.1)$ & $4.3(1.5)$ & $<.01$ \\
\hline $\begin{array}{l}\text { How consistently does your clinic provide mortality acknowledgment (including preparation for death, } \\
\text { advance care planning and goals of care discussions) to patients with chronic, progressive, life-limiting } \\
\text { illnesses? }\end{array}$ & $4.3(1.2)$ & $3.3(1.5)$ & $<.01$ \\
\hline $\begin{array}{l}\text { How consistently does your clinic use the allied health team (from your clinic) for patients with chronic, } \\
\text { progressive, life-limiting illnesses? }\end{array}$ & $5.1(1.5)$ & $3.5(1.6)$ & $<.01$ \\
\hline $\begin{array}{l}\text { How consistently does your clinic use external allied clinician resources (from the community) for patients } \\
\text { with chronic, progressive, life-limiting illnesses? }\end{array}$ & $4.7(1.4)$ & $4.2(1.5)$ & 0.01 \\
\hline $\begin{array}{l}\text { How consistently does your clinic address the needs of the caregiver for patients with chronic, progressive, } \\
\text { life-limiting illnesses? }\end{array}$ & $4.7(1.4)$ & $3.9(1.4)$ & $<.01$ \\
\hline $\begin{array}{l}\text { How consistently does your clinic assess and manage symptoms of patients with chronic, progressive, life- } \\
\text { limiting illnesses? }\end{array}$ & $5.5(1.1)$ & $5.0(1.2)$ & .01 \\
\hline
\end{tabular}

planning (90\% vs $13.6 \% ; p<0.01)$; community home care nurse involvement ( $85 \%$ vs $25.4 \% ; p<0.01)$; FHT practice nurse involvement (70\% vs $35.6 \%$; $p<0.01)$; documentation of existential, psychosocial or spiritual concerns ( $80 \%$ vs $28.8 \% ; p<0.01$ ); and documentation related to addressing caregiver well-being $(45.0 \%$ vs $5.1 \%$; $p<0.01)$. PAC patients were also more likely than non-PAC patients to receive frequent ( 5 or more) phone calls $(75 \%$ versus $32.1 \% ; p<0.01)$. Compared to patients who did not receive PAC, PAC patients tended to have more home visits (mean 4 versus 1.7 visits; $p=0.21$ ). Allied health professionals of the FHT were infrequently involved.

Among the FHT clinicians who attended the presentation of results, $33.3 \% \%$ were physicians, $29.2 \%$ were residents, $16.7 \%$ were nurses, $14.6 \%$ were allied health professionals and $6.3 \%$ were support staff. After the presentation, the mean ratings of perceived consistency of delivering a palliative approach decreased statistically significantly $(p<0.05)$ for all questions (Table 3$)$. The care process rated by clinicians as lowest before seeing results was having goals of care conversations (mean $=4.3$, $\mathrm{SD}=1.2$ ). The item with the largest reduction in perceived consistency was for involvement of FHT allied health professionals (mean before $=5.1, \mathrm{SD}=1.5$; mean after $=3.5 \mathrm{SD}=1.6$ ).

\section{Discussion}

In this study of the care of patients in their last year of life by their family practice, one-quarter of patients were assessed as having received PAC. PAC was evident for patients with cancer and non-cancer illnesses. Documentation of advance care planning discussions, clinic and community homecare nursing involvement, addressing psychosocial and spiritual needs, and addressing caregiver wellness were care processes that distinguished between patients receiving PAC and not receiving PAC. In previous research, family physicians reported feeling capable of meeting the palliative needs of many patients $[2,39]$, however they have also reported doing so without a specific plan or approach [40]. Patients with progressive life-limiting illness have varying needs over the last year of life, beyond medical treatment for physical symptoms. The presence of additional aspects of care including discussions about goals of care, mobilizing more resources to care for the patient in the community and involving and supporting caregivers were also present for patients receiving $\mathrm{PAC}$.

It was interesting that symptoms were addressed for a high proportion of patients as indicated in notes in the chart, however specific assessment tools were rarely used. This could be due to the lack of routine use of a specific set of palliative care tools in the common electronic medical record used by the practices. Routine use of a structured tool may trigger a broader assessment of symptoms including psychosocial and spiritual issues [41], however in primary care their use is generally low [42] and this represents a potential area for improvement.

Historically the evidence for palliative care has emerged from studies of patients with cancer, however there is increasing recognition of the palliative needs of people with non-cancer diagnoses [6]. Our study reveals the application of a palliative approach to care for patients with several other chronic, progressive life-limiting illnesses. Patients with cancer tend to have a defined and 
short terminal phase, characterized by step-wise drops in function and they are more likely to receive formal palliative care services and for longer periods before death, compared to non-cancer illnesses [43, 44]. The duration of non-cancer palliative needs can be longer and less certain than that for cancer $[37,44]$ and the needs of patients with non-cancer life-limiting illnesses can be less intense over this prolonged period, making early identification a challenge. This could be one reason that only $25 \%$ of patients received a PAC in their last year of life, as most deaths were non-cancer related.

Family medicine, being a community-based discipline that prioritizes the patient-physician relationship, is in a unique position to build upon the care processes that we have operationalized for a PAC [45]. Presentation of the study results shifted the FHT clinicians' perception of the consistency with which PAC is applied by the clinic and the new information provided specific and tangible areas to focus on for improvement. The fact that FHT clinicians changed their perceptions suggests that although the care is often present, there is opportunity to be more intentional about naming and providing it.

This study has some limitations. The study was conducted in one setting and may not be representative of all Canadian family practices, however the clinics are part of a large practice-based research network with approximately 40 physicians. Our consensus process to define the elements of a palliative approach in family practice through chart review was done with experts from a single academic institution rather than multiple institutions and jurisdictions. However, the team has specialized knowledge through clinical practice, education, and health system leadership in the area of integration of a primary palliative approach in family practice. We were not able to assess if care was proactive and responsive to patient and caregiver needs, therefore we cannot comment on quality of care. Finally, the judgement of whether PAC was present reflected an overall expert assessment rather than an empirically driven approach, and it was not independent of domains in the chart review. It will be important to empirically validate the care processes that comprise a palliative approach in a larger multi-centre study.

\section{Conclusions}

Our study operationalized care indicators that can be used to describe the extent to which PAC is applied, which may help efforts to ensure equitable access and quality care. Measuring what family physicians and other primary care clinicians are already doing as part of routine practice highlights processes that can be leveraged and enhanced. The distinguishing processes of PAC we observed reinforced conceptual definitions of PAC and are within the scope of family medicine and did not require specialized palliative medicine physicians or additional resources that are not already available in family practice. Our results, which highlight how primary care can provide a palliative approach as part of routine practice, can benefit models of health care that seek to optimize the relationship between primary care and specialized palliative care resources and community resources. The findings can also assist these groups to implement an integrated palliative approach to care across different sectors. Future research will need to explore patient, family member and caregiver perceptions around the operationalized elements of a palliative approach to care and how they are experienced. This could shape any future interventions and identified outcomes measures.

Abbreviations

FHT: Family Health Team; PAC: Palliative approach to care.

\section{Supplementary Information}

The online version contains supplementary material available at https://doi. org/10.1186/s12875-021-01400-4.

Additional file 1. Chart Review Tool. This chart review tool was developed by this study to capture the elements of PAC in primary care.

Additional file 2. Pre- \& Post-Chart Review Questionnaire. The questionnaire was developed by this study and has not been published elsewhere.

Acknowledgements

Not applicable.

Authors' contributions

$\mathrm{EG}, \mathrm{MH}, \mathrm{SW}, \mathrm{NH}, \mathrm{AM}$ conceived of the study. DR, KB, AH collected the data. AH analyzed the data. All authors interpreted the results. EG and $\mathrm{MH}$ wrote the manuscript. All authors critically revised the manuscript. All authors read and approved the final manuscript.

\section{Funding}

The study was funded by a grant from the Department of Family Medicine, McMaster University. The funder had no role in the design of the study and collection, analysis, and interpretation of data and in writing the manuscript.

Availability of data and materials

The anonymized data used and analysed during the current study are available from the corresponding author on reasonable request.

\section{Declarations}

Ethics approval and consent to participate

The chart review study was approved by the Hamilton Integrated Research Ethics Board (\#4204). We did not seek ethics approval for the anonymous staff questionnaire as this was undertaken to inform potential quality improvement efforts locally, as per Canada's Tri-Council Policy Statement: Ethical Conduct for Research Involving Humans -TCPS 2 (2018) Article 2.5. Individual respondent consent was not elicited and was assumed by completion of the questionnaire. 


\section{Consent for publication}

Not applicable.

\section{Competing interests}

The authors declare that they have no competing interests.

\section{Author details}

'Department of Family Medicine, McMaster University, David Braley Health Sciences Centre 100 Main Street West, 5th Floor, Hamilton, ON L8P 1H6, Canada. ${ }^{2}$ Division of Palliative Care, McMaster University, David Braley Health Sciences Centre 100 Main Street West, 5th Floor, Hamilton, ON L8P 1H6, Canada. ${ }^{3}$ Division of Palliative Care, Department of Medicine, University of Ottawa, 451 Smyth, Road Ottawa, Ottawa, ON K1H 8M5, Canada. ${ }^{4}$ Department of Palliative Care, Bruyere Continuing Care, 43 Bruyère St, Ottawa, ON K1N 5C8, Canada.

Received: 4 August 2020 Accepted: 23 February 2021

Published online: 27 March 2021

\section{References}

1. Beernaert K, Deliens L, De Vleminck A, Devroey D, Pardon K, Van den Block L, Cohen J. Early identification of palliative care needs by family physicians: A qualitative study of barriers and facilitators from the perspective of family physicians, community nurses, and patients. Palliat Med. 2014;28:480-90.

2. Rewegan A, Danho S, White J, Winemaker S, Hansen N, MacLennan A, Howard M. How do physicians and nurses in family practicedescribe their care for patients with progressive life-limiting illness? A qualitative study of a 'palliative approach'. Prim Health Care Res Dev. 2019;20(e95):1-7.

3. Smith G, Bernacki R, Block SD. The role of palliative care in population management and accountable care organizations. J Palliat Med. 2015;18:486-94.

4. Temel JS, Greer JA, Muzikansky A, Gallagher ER, Admane S, Jackson VA, Dahlin CM, Blinderman CD, Jacobsen J, Pirl WF, et al. Early palliative care for patients with metastatic non-small-cell lung cancer. New Engl J Med. 2010;363:733-42

5. Zimmermann C, Swami N, Krzyzanowska M, Hannon B, Leighl N, Oza A, Moore M, Rydall A, Rodin G, Tannock I, et al. Early palliative care for patients with advanced cancer: a cluster-randomised controlled trial. Lancet (London, England). 2014;383:1721-30.

6. Quinn KL, Shurrab M, Gitau K, Kavalieratos D, Isenberg SR, Stall NM, Stuke TA, Goldman R, Horn D, Cram P, et al. Association of receipt of palliative care interventions with health care use, quality of life, and symptom burden among adults with chronic noncancer illness: a systematic review and meta-analysis. JAMA. 2020;324(14):1439-50.

7. Sleeman KE, de Brito M, Etkind S, Nkhoma K, Guo P, Higginson IJ, Gomes $B$, Harding R. The escalating global burden of serious health-related suffering: projections to 2060 by world regions, age groups, and health conditions. Lancet Glob Health. 2019;7(7):e883-92.

8. Canadian Hospice Palliative Care Association. A model to guide hospice palliative care: based on national principles and norms of practice. 2013 Retrieved from the Canadian Hospice Palliative Care Association website: https://www.chpca.ca/wp-content/uploads/2019/12/norms-of-practiceeng-web.pdf.

9. Sawatzky R, Porterfield P, Lee J, Dixon D, Lounsbury K, Pesut B, Roberts D, Tayler C, Voth J, Stajduhar K. Conceptual foundations of a palliative approach: a knowledge synthesis. BMC Palliat Care. 2016;15:5

10. Shaw EA, Marshall D, Howard M, Taniguchi A, Winemaker SA, Burns S. Systematic review of postgraduate palliative care curricula. J Palliat Med. 2010;13(9):1091-108.

11. Tapsfield J, Hall C, Lunan C, McCutcheon H, McLoughlin P, Rhee J, Leiva A, Spiller J, Finucane A, Murray SA. Many people in Scotland now benefit from anticipatory care before they die: an after death analysis and interviews with general practitioners. BMJ Support Palliat Care. 2019;9(4):e28

12. Murray SA, Kendall M, Mitchell G, Moine S, Amblas-Novellas J, Boyd K. Palliative care from diagnosis to death. BMJ. 2017;356:j878.

13. World Health Organization: WHO | Palliative Care. Fact Sheet. 2017 Retrieved from World Health Organization website: https://www.who.int/ features/factfiles/palliative-care/en/.
14. Meier DE, Back AL, Berman A, Block SD, Corrigan JM, Morrison RS. A national strategy for palliative care. Health Aff (Millwood) 2017:36(7):1265-73.

15. Morrison RS. A national palliative care strategy for Canada. J Palliat Med 2018;21(S1):S63-75.

16. Canadian Institute for Health Information. 2018. Access to palliative care in Canada. Retrieved from Canadian Institute for Health Information website: https://www.cihi.ca/sites/default/files/document/access-palli ative-care-2018-en-web.pdf.

17. Canadian Hospice Palliative Care Association. 2014. The way forward - moving towards an integrated palliative approach to care: survey of GP/FPs and nurses in primary care. Retrieved from Canadian Hospice Palliative Care Association website: http://www.hpcintegration.ca/ resources/health-care-professional-research/primary-care-research. aspx

18. Health Canada. Framework on palliative care in Canada. 2018. Retrieved from the Government of Canada website: https://www. canada.ca/en/health-canada/services/health-care-system/reportspublications/palliative-care/framework-palliative-care-canada.html.

19. Touzel M, Shadd J. Content validity of a conceptual model of a palliative approach. J Palliat Med. 2018;21:1627-35.

20. Ernecoff NC, Check D, Bannon M, Hanson LC, Dionne-Odom JN, Corbelli J, Klein-Fedyshin M, Schenker Y, Zimmermann C, Arnold RM, et al. Comparing specialty and primary palliative care interventions: analysis of a systematic review. J Palliat Med. 2020;23(3):389-96.

21. Shadd JD, Burge F, Stajduhar KI, Cohen SR, Kelley ML, Pesut B. Defining and measuring a palliative approach in primary care. Can Fam Physician. 2013:59(11):1149-50.

22. Quill TE, Abernethy AP. Generalist plus specialist palliative care — creating a more sustainable model. N Engl J Med. 2013;368:1173-5.

23. Murray SA, Firth A, Schneider N, Van den Eynden B, Gomez-Batiste X, Brogaard T, Villanueva T, Abela J, Eychmuller S, Mitchell G, et al. Promoting palliative care in the community: production of the primary palliative care toolkit by the European Association of Palliative Care Taskforce in primary palliative care. Palliat Med. 2015;29:101-11.

24. College of Family Physicians of Canada. A vision for Canada: family practice - the patient's medical home. 2011. Retrived from the Patient's Medical Home website: https://patientsmedicalhome.ca/resources/pastvision-papers/2011-pmh-vision-paper/.

25. Mangin D. The contribution of primary care research to improving health services. In: Goodyear-Smith F, Mash B, editors. International perspectives on primary care research. London: CRC Press; 2017.

26. Beernaert K, Van den Block L, Van Thienen K, Devroey D, Pardon K, Deliens $\mathrm{L}$, Cohen J. Family physicians' role in palliative care throughout the care continuum: stakeholder perspectives. Fam Pract. 2015;32:694-700.

27. Mitchell GK. How well do general practitioners deliver palliative care? A systematic review. Palliat Med. 2002;16:457-64.

28. Mitchell S, Loew J, Millington-Sanders C, Dale J. Providing end-of-life care in general practice: findings of a national GP questionnaire survey. $\mathrm{Br} J$ Gen Pract. 2016;66(650):e647-53.

29. van Den Block L. Palliative care in primary care. In: Cohen J, Deliens L, editors. A public health perspective on end of life care. London: Oxford Scholarship Online: 2012

30. Beernaert K, Deliens L, Vleminck AD, Devroey D, Pardon K, Block $\mathrm{LVd}$, Cohen J. Is there a need for early palliative care in patients with life-limiting illnesses? Interview study with patients about experienced care needs from diagnosis onward. Am J Hospice Palliat Care. 2015:33(4):489-97.

31. Murray SA, Mitchell GK, Burge F, Barnard A, Nowels D, Charlton R. It's time to develop primary care services for the dying. J Palliat Care. 2006;22(2):115-6

32. Green E, Knight S, Gott M, Barclay S, White P. Patients' and carers' perspectives of palliative care in general practice: a systematic review with narrative synthesis. Palliat Med. 2018;32(4):838-50.

33. Baker R, Freeman GK, Haggerty JL, Bankart MJ, Nockels KH. Primary medical care continuity and patient mortality: a systematic review. $\mathrm{Br} J \mathrm{Gen}$ Pract. 2020;70(698):e600-e611.

34. Ankuda CK, Petterson SM, Wingrove P, Bazemore AW. Regional variation in primary care involvement at the end of life. Annals Fam Med. 2017;15:63-7. 
35. Pereira J, Chary S, Moat JB, Faulkner J, Gravelle-Ray N, Carreira O, Vincze D, Parsons G, Riordan B, Hayawi L, et al. Pallium Canada's curriculum development model: a framework to support largescale courseware development and deployment. J Palliat Med. 2020;23(6):759-66

36. Shipman C, Gysels M, White P, Worth A, Murray SA, Barclay S, Forrest S, Shepherd J, Dale J, Dewar S, et al. Improving generalist end of life care: national consultation with practitioners, commissioners, academics, and service user groups. BMJ (Clinical research ed). 2008;337:a1720.

37. Gill TM, Gahbauer EA, Han L, Allore HG. Trajectories of disability in the last year of life. New Engl J Med. 2010;362(13):1173-80.

38. Highet G, Crawford D, Murray SA, Boyd K. Development and evaluation of the Supportive and Palliative Care Indicators Tool (SPICT): a mixedmethods study. BMJ Support Palliat Care. 2014;4(3):285-90.

39. Beernaert K, Deliens L, Pardon K, Van den Block L, Devroey D, Chambaere K, Cohen J. What are physicians' reasons for not referring people with life-limiting illnesses to specialist palliative care services? A nationwide survey. PLoS One. 2015;10(9):e0137251.

40. Deckx L, Mitchell G, Rosenberg J, Kelly M, Carmont SA, Yates P. General practitioners' engagement in end-of-life care: a semi-structured interview study. BMJ Support Palliat Care. Published Online First: 03 September 2019. https://doi.org/10.1136/bmjspcare-2019-001817.

41. Hui D, Bruera E. The Edmonton symptom assessment system 25 years later: past, present, and future developments. J Pain Symptom Manage. 2017;53(3):630-43.

42. Maas EA, Murray SA, Engels Y, Campbell C. What tools are available to identify patients with palliative care needs in primary care: a systematic literature review and survey of European practice. B BMJ Support Palliat Care. 2013;3(4):444-51.

43. Lunney JR, Lynn J, Foley DJ, Lipson S, Guralnik JM. Patterns of functional decline at the end of life. JAMA. 2003;289:2387-92.

44. Murray SA, Kendall M, Boyd K, Sheikh A. Illness trajectories and palliative care. BMJ. 2005:330(7498):1007-11.

45. Mitchell G, Murray SA. Supportive and palliative care in the age of deferred death: primary care's central role. BMJ Support Palliat Care. Published Online First: 24 September 2020. https://doi.org/10.1136/ bmjspcare-2020-002616.

\section{Publisher's Note}

Springer Nature remains neutral with regard to jurisdictional claims in published maps and institutional affiliations.

Ready to submit your research? Choose BMC and benefit from:

- fast, convenient online submission

- thorough peer review by experienced researchers in your field

- rapid publication on acceptance

- support for research data, including large and complex data types

- gold Open Access which fosters wider collaboration and increased citations

- maximum visibility for your research: over $100 \mathrm{M}$ website views per year

At BMC, research is always in progress.

Learn more biomedcentral.com/submissions 